\title{
Corrigendum: Impact of Player Injuries on Teams' Mental States, and Subsequent Performances, at the Rugby World Cup 2015
}

\author{
Olivia A. Hurley* \\ Department of Technology and Psychology, Faculty of Film, Art and Creative Technologies, Dun Laoghaire Institute of Art, \\ Design and Technology, Dublin, Ireland
}

Keywords: rugby, challenges, injury, social contagion, team ethos, equality, technology, virtual reality

\section{OPEN ACCESS}

Edited and reviewed by:

Tadhg Eoghan Maclntyre,

University of Limerick, Ireland

${ }^{*}$ Correspondence:

Olivia A. Hurley

olivia.hurley@iadtie

Specialty section: This article was submitted to Movement Science and Sport

Psychology,

a section of the journal

Frontiers in Psychology

Received: 30 June 2016 Accepted: 14 July 2016

Published: 27 July 2016

Citation: Hurley OA (2016) Corrigendum: Impact of Player Injuries on Teams' Mental States, and Subsequent Performances, at the Rugby World Cup 2015. Front. Psychol. 7:1127.

doi: 10.3389/fpsyg.2016.01127

\section{A corrigendum on}

Impact of Player Injuries on Teams' Mental States, and Subsequent Performances, at the Rugby World Cup 2015

by Hurley, O. A. (2016). Front. Psychol. 7:807. doi:10.3389/fpsyg.2016.00807

Reason for Corrigendum:

There was a mistake in the author's affiliation as published in the Opinion article. The correct affiliation is Department of Technology and Psychology and not Department of Technology and Technology as reported.

The author apologizes for the mistake. This error does not change the content or opinions put forward in the opinion article as published.

\section{AUTHOR CONTRIBUTIONS}

The author confirms being the sole contributor of this work and approved it for publication.

Conflict of Interest Statement: The author declares that the research was conducted in the absence of any commercial or financial relationships that could be construed as a potential conflict of interest.

Copyright (c) 2016 Hurley. This is an open-access article distributed under the terms of the Creative Commons Attribution License (CC BY). The use, distribution or reproduction in other forums is permitted, provided the original author(s) or licensor are credited and that the original publication in this journal is cited, in accordance with accepted academic practice. No use, distribution or reproduction is permitted which does not comply with these terms. 